\title{
SRI single seedling transplanting implement: an innovative technique to challenges on SRI planting and spacing techniques
}

\author{
${ }^{1}$ Bashar Z.U., ${ }^{1}$ Graham W.B.R, ${ }^{2,3}$ Aimrun W. and ${ }^{2}$ Razif M.M. \\ ${ }^{1}$ Department of Agricultural and Bio-Environmental Engineering, Waziri Umaru Federal Polytechnic, B/ \\ Kebbi, Kebbi State, Nigeria \\ ${ }^{2}$ Department of Biological and Agricultural Engineering, Faculty of Engineering, Universiti Putra \\ Malaysia, 43400 Serdang, Selangor Darul Ehsan, Malaysia. \\ ${ }^{3}$ SMART Farming Technology Research Centre, Faculty of Engineering, Universiti Putra Malaysia, 43400 \\ Serdang, Selangor Darul Ehsan, Malaysia
}

\section{Article history:}

Received: 8 June 2018

Received in revised form: 11 October 2018

Accepted: 17 October 2018

Available Online: 14

November 2018

\section{Keywords:}

System of Rice

Intensification,

Conventional Transplanters,

Spacing Patterns,

Missing Hills,

Loosening Index

\section{DOI:}

https://doi.org/10.26656/fr.2017.3(2).118

\begin{abstract}
In rice production, seedling quality and transplanting potentials stand as a prerequisite for proper completion of rice production for optimum yield. The overall objective of this research was to develop a transplanting implement capable of placing rice seedling singly into the field by dropping with respect to SRI planting conditions. It is aimed at using seedlings established from SRI-tray designed with adjustable spacing options of within and between rows of $25 \mathrm{~cm}, 30 \mathrm{~cm}$ and $40 \mathrm{~cm}$ leading to nine SRI spacing options to suite SRI practitioners' preference. Performance evaluation was based on suitable growing media, planting speed, percentages of single, missing and multiple planting as well as field capacity and field efficiency. The data revealed that the speed of operation at $0.18 \mathrm{~m} / \mathrm{s}$ reported the highest significance percentage of single planting when subjected to spacing patterns of $25 \times 35 \mathrm{~cm}(84 \%), 25 \times 25 \mathrm{~cm}(81 \%), 30 \times 30 \mathrm{~cm}(73 \%)$ and $40 \times 40 \mathrm{~cm}$ $(83 \%)$. But, a decreasing trend was recorded when the speed increased to $0.45 \mathrm{~m} / \mathrm{s}$. The performance recorded were $53 \%, 56 \%$ and $72 \%$ on $25 \times 35 \mathrm{~cm}, 25 \times 25 \mathrm{~cm}$ and $30 \times 30$ $\mathrm{cm}$ spacing patterns respectively with a surprising performance stability of $83 \%$ on the 40 $\times 40 \mathrm{~cm}$. The results on growing media indicated that clay with compost had the highest significance with respect to the weight of seedling $(25.3 \mathrm{~g})$ giving the loosening index of 66 seconds and the planting depth of $16 \mathrm{~mm}$. At the speed of $0.18 \mathrm{~m} / \mathrm{s}$, the field capacity was $1.29 \mathrm{ha} / \mathrm{hr}$ and, the field efficiency was $79.5 \%$ but, changed to $1.55 \mathrm{ha} / \mathrm{hr}$ and $75 \%$ respectively, at the speed of $0.45 \mathrm{~m} / \mathrm{s}$.
\end{abstract}

\section{Introduction}

Rice (Oryza sativa L.) in Asia or (Oryza glaberrima) in Africa stands as a staple food to most of the world's human population with the highest consumption in the Asian region. It is classified as the third - highest worldwide production after Sugarcane and Maize (FAOSTAT, 2012). Research has indicated that it is a good source of protein and also plays a vital role in nutrition to much more number of world populations with a significant figure in Asia, Latin America and Africa (Brown and Funk, 2008; Bruinsma, 2009; Godfray et al., 2010; FAO et al., 2012). According to FAOSTAT (2012), this versatile crop represents a central food security to over half of the world populations.

The requirements of SRI systems are to transplant single seedling at a very young age of about 8 to 10 days after seed germination in a nursery with an innovative spacing of $20 \times 25 \mathrm{~cm}, 25 \times 25 \mathrm{~cm}, 30 \times 30 \mathrm{~cm}$ or $40 \mathrm{x}$ $40 \mathrm{~cm}$ or even more depending on field topography and soil fertility. Despite all these versatile opportunities on SRI-rice production practices, the current techniques of seedling transplanting still remain a challenging constraint among SRI practitioners as the existing transplanting machines do not accurately respond to the full SRI transplanting conditions of single seedling per hill with respect to SRI spacing patterns geometry. Although, several attempts were made by different researchers on the modification of the existing transplanting machines to satisfy full SRI mechanized farming (Chiu and Fon, 2000; Dixit et al., 2007; Ersson et al., 2011; Hussain et al., 2013; Dhananchezhiyan et al., 2013), but still the problem of multiple planting per hill, noticeable percentage of unplanted hills and non- 
compliance of SRI spacing standards within and between rows continue to remain as farmers nightmare.

Consequently, the only promising practice that accurately tallies with the SRI principles is manual transplanting, but it engulfs high labor requirement ranging from 180-250 man/hr/ha (Dixit et al., 2007; Farooq et al., 2011; Joshi et al., 2013) and others stresses of long hours of bending with barefooted in the puddled field, transplanting shock as a result of pulling and less profitable as the resources are becoming increasingly scarce among others. Therefore, in order to wipe away these existing stresses of manual transplanting as well as reducing the transplanting shock experienced by the young rice plant and other hindering production costs, the new innovative transplanting implement has been set on board and tagged as "SRI Single Seedling Transplanting Implement: Innovative Technique to Challenges on SRI Planting and Spacing Techniques". The developed technique in this study is aimed to serve as a pathway in addressing the issues relating to full compliance of SRI planting and spacing mechanization to enhance its sustainability.

\section{Materials and methods}

The present study involved an observational framework on the cultivation of rice in accordance with the full mechanization of SRI planting and spacing principle. This relates to the development of the most suitable transplanting implement capable of placing/ planting single soil bearing seedling per hill with respect to SRI spacing patterns.

The SRI single seedling transplanting implement was designed to use soil bearing seedling type with preference to the seedlings established from SRI-tray that provides root separated seedling coupled with soil. Selection on the suitable media that grantee the design objective of proposed transplanting implement was carefully conducted using the most common soils found in the fadama fields (loam and clay soils).

\subsection{Adjustable spacing patterns}

Spacing pattern plays a major key role in SRI rice production, therefore, much interest was bestowed on how best the SRI spacing standards could be achieved to its full mechanized transplanting technique. This single seedling transplanting implement was designed with three adjustable spacing patterns $(25 \mathrm{~cm}, 30 \mathrm{~cm}$ and 40 $\mathrm{cm})$ for both within and between the rows leading to nine optional patterns $(25 \mathrm{~cm} \times 25 \mathrm{~cm}, 25 \mathrm{~cm} \times 30 \mathrm{~cm}, 25 \mathrm{~cm}$ $\times 40 \mathrm{~cm}, 30 \mathrm{~cm} \times 25 \mathrm{~cm}, 30 \mathrm{~cm} \times 30 \mathrm{~cm}, 30 \mathrm{~cm} \times 40$ $\mathrm{cm}, 40 \mathrm{~cm} \times 25 \mathrm{~cm}, 40 \mathrm{~cm} \times 30 \mathrm{~cm}$ and $40 \mathrm{~cm} \times 40 \mathrm{~cm})$ depending on the farmers' preference as well as on the topography and the fertility of the transplanting site. Therefore, the selection of the spacing pattern between rows was designed based on the seedling guide.

\subsection{Soil-machine relationship}

The SRI single seedling transplanting implement was designed to use soil bearing seedling type with preference to the seedlings established from SRI-tray that provides root separated seedling coupled with soil. Selection on the suitable media that guarantees the design objective of proposed transplanting implement was carefully conducted using the most common soils found in the fadama fields (loam and clay soils). In achieving the suitable media for raising soil bearing seedling, different composition of soils was made and analyzed in order to come up with the most suitable soil capable of completing the planting objective. These include Clay + compost $\left(\mathrm{M}_{1}\right)$, Clay alone $\left(\mathrm{M}_{2}\right)$, Loam + compost $\left(\mathrm{M}_{3}\right)$ and Clay + Loam + compost $\left(\mathrm{M}_{4}\right)$ and the parameters taken into consideration were loosening index $(\mathrm{Li})$, free falling analysis from the gated opener by analyzing the weight and the related distance from the opener to the ground, stability of the seedling after falling and recovery of the seedling after three days of transplanting. Likewise, the volume of media required per planting area was also computed using Equation (1).

$$
V_{m}=A \times h
$$

Where $V_{m}$ is the volume of media $\left(\mathrm{m}^{3}\right) ; A$ is the area occupied by the growing media; and $h$ represents the height of the growing cavity.

\subsection{Seedling number per planting area}

The number of required to plant one hectare of puddled field according to SRI spacing was also computed in order to know the number of trays to be purchased for nursery preparation. Equation (2) was used in determining this value.

$$
S_{n}=\frac{A}{S_{p t}}
$$

Where $S_{n}$ is number of seedlings; $A$ is area $\left(\mathrm{m}^{2}\right)$; and $S_{p t}$ represents spacing pattern $\left(\mathrm{m}^{2}\right)$

\subsection{Percentages of single seedling planting, missing hill and multiple planting per area}

The number of hills with planted single seedling was recorded upon randomly selected square meter $\left(\mathrm{m}^{2}\right)$ and with three replications to minimize the error for each of the proposed nine spacing options and the average was taken from each. The data was recorded in percentage with respect to the number of seedlings required per meter square and were evaluated per hectare. The similar method was also used in determining the percentage of 
missing hills as well as the percentage of multiple planting per hill.

\subsection{The field efficiency}

This represents the difference between the actual field capacity and that of the theoretical field capacity and expressed in percentage as shown in Equation (3) as reportedly employed on the performance evaluation of farm machineries (Behera et al., 2009; Manjunatha et al., 2009; Madusanka, 2011; Murumkar et al., 2015).

$$
\text { Field efficiency }(\%)=\frac{\text { Actual field capacity }}{\text { Theoretical field capacity }}
$$

\subsection{Actual field capacity}

This was considered as the area covered by the actual time taken to cover that area including the time lost in turning and reloading of seedlings while the theoretical field capacity was defined as the forwarding speed by the width of the machine with Equation (4).

$$
\text { Actual field capcity }(\mathrm{ha} / \mathrm{hr})=\frac{A}{T_{H}+T_{R}+T_{W}}
$$

Where $\mathrm{A}=$ Area (ha); $\mathrm{T}_{\mathrm{H}}=$ Turning head (hr); $\mathrm{T}_{\mathrm{R}}=$ Loading time (hr); and $\mathrm{T}_{\mathrm{W}}=$ Working time ( $\mathrm{hr}$ )

The theoretical field is the rate of field coverage that would be obtained if the transplanting implement was operating continuously without interruptions of reloading time and turning head or speed of the operation by the width of the coverage (machine). This can be expressed in Equation (5) as used by Adebija and Jackson, (2013).

Theoretical field capacity $(h a / h r)=\frac{w \times s}{10}$

Where $\mathrm{w}=$ Width of the coverage $(\mathrm{m})$; and $\mathrm{S}=$ Speed of operation (kmph)

\subsection{Statistical analysis}

The data were statistically analyzed by analysis of variance (ANOVA) technique as applicable to random complete block design (RCBD) based on the statistical analysis software (SAS 9.2 for Windows). Duncan's multiple ranging tests (DMRT) was used to evaluate the differences between the treatment means at $5 \%$ probability level.

\section{Results and discussion}

\subsection{Adjustable spacing within rows}

The gearing arrangement of the driven shaft composed of 32 teeth, 24 teeth and 20 teeth sprockets which were designed to mate with the driver sprocket of 32 teeth from the planting wheel; it was made with the fundamental aim of generating three optional revolutions and/or rotations to be chosen according to the requirement of SRI spacing conditions with the help of the gear shifter or selector in three distinct positions.
These positions were designed and developed to work on a 1-2-3 shifting basis (position one [1] was to put 20 teeth sprocket on the run with the driver 32 teeth; position two [2] was to combine 24 teeth with 32 teeth of the driver sprocket and position three [3] was set to work on one on one of both 32 teeth between the driver and the driven sprockets). The computation of the transplanting spacing was evaluated by considering the perimeter of the transplanting wheel $(800 \mathrm{~mm})$ and the gear ratio obtained when connected to one another. In obtaining the spacing of $300 \mathrm{~mm}$ within a row, the combination of 32 teeth (driver) to 24 teeth (driven) was made and resulted in a gear ratio of 0.75 . When multiplied with the perimeter $(800 \mathrm{~mm})$, it provided a displacement of $600 \mathrm{~mm}$ on the ground. Therefore, considering the opening and closing of the gated opener (having a downward and upward movement per one complete revolution of the driven shaft) this lead to a ground displacement of opening at $300 \mathrm{~mm}$ and closing at $300 \mathrm{~mm}$ with respect to the two operations of the gated opener (opening at $180^{\circ}$ and closing at $180^{\circ}$ ). The same computational method was adopted for the other two spacing options $(250 \mathrm{~mm}$ and $400 \mathrm{~mm})$ with gear ratio of 0.62 and 1 , respectively and whose positioning was based on the farmers and/or spacing preference as well as the topography and fertility of the rice-growing environment. Similar methods were reported with the conventional transplanting machine although non-SRI compliance reasons to fact that the spacing options provided by this machine did not tally with the recommended spacing pattern designed by SRI planting and spacing techniques (Manjunatha et al., 2009; Hussain et al., 2013; Lutfar Rahman, 2013; Ojha and Kwatra, 2014; Murumkar et al., 2015). Their findings revealed that although the common spacing options were $120,140,160,180$ and $210 \mathrm{~mm}$ for the spacing within row, but other attempts were also made on the improvement of planting and spacing pattern with adjustment on the picking fingers with the sole target of transplanting seedling singly in the puddled field deviating from the clumps transplanting in order to closely tally with the SRI planting conditions.

\subsection{Adjustable spacing between rows}

The adjustment of spacing between rows was powered based on the fixed replaceable seedling guide made in three pieces each representing a specified SRI spacing standard. The seedling guide was made to control the spacing between rows fixed at $25 \mathrm{~cm}, 30 \mathrm{~cm}$ and $40 \mathrm{~cm}$ on replaceable manner i.e. depending on the farmer's preference on the spacing. Therefore, for a spacing of $25 \mathrm{~cm}$, a seedling guide whose orifices (seedling chambers) were spaced at $25 \mathrm{~cm}$ was used that enabled the transplanting of up to 10 seedlings (10 rows) 
per single opening of the gate through the seedlings queuing chamber (control the queuing of the seedlings before falling into the field) (Figure 1). Likewise, when the spacing was changed to $30 \mathrm{~cm}$ interval between rows, 8 rows seedling guide was used that facilitate the transplanting or placing of 8 seedlings per single opening of the gated opener. However, when the spacing was fixed at $40 \mathrm{~cm}$ interval between rows, it resulted in placing 6 seedlings into the puddled field. The similar arrangement was also found on the conventional transplanting machine although with one single option of mostly $30 \mathrm{~cm}$ (Pateriya and Datta, 2012; Selvan et al., 2014; Murumkar et al., 2015).

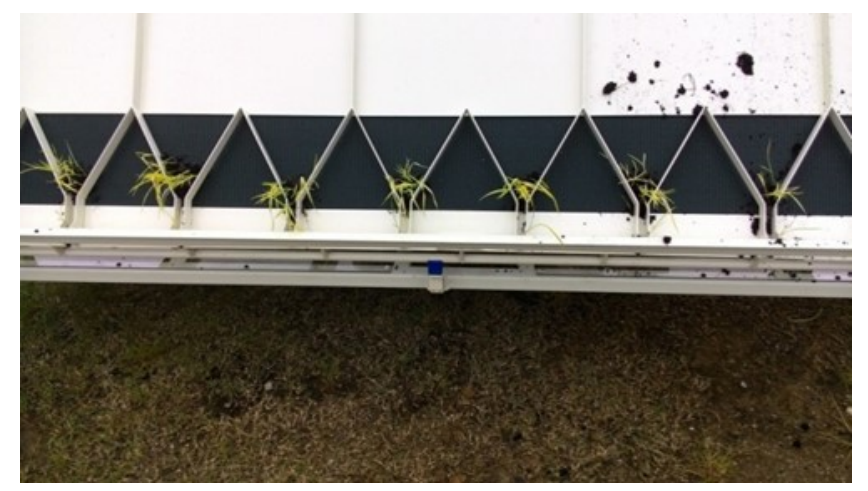

Figure 1. Assembled seedling guide fixed at $25 \mathrm{~cm}$

3.3 Percentage of single seedling planting per $m^{2}$ at varying speeds

As SRI is aimed at improving the quality and transplanting potential of the young sprouted rice seedling for safe and peaceful landing in the puddled field without transplanting shock, the transplanting of the semi-dried seedling with clay soil was tested at varying speeds so as to have the most reliable and effective transplanting rate with less damages and free from transplanting shock (Zubairu et al., 2015). Therefore, data from the field test revealed that seedlings planted with SRI spacing pattern of $25 \times 30 \mathrm{~cm}$ have indicated the highest number of single seedling planting of virtually 10 out of 13 seedlings at working speed $S_{1}$, but the trend changed when subjected to $25 \times 25 \mathrm{~cm}$ having 9 out of 16 seedlings and leading to the collection of 3 out 6 seedlings at the same working speed for $40 \times 40$ $\mathrm{cm}$ spacing patterns. This was obtained from the randomly selected square meter in three replications to minimize error; the counting was made to ascertain the number of singly planted seedlings with respect to the nine (9) optional SRI spacing patterns improvised by the implement. Similarly, the ANOVA and DMRT revealed that seedlings planted at a spacing pattern of $25 \times 25 \mathrm{~cm}$, $25 \times 30 \mathrm{~cm}$ and $25 \times 40 \mathrm{~cm}$ have indicated a significant influence with respect to the speed of operation $\left(\mathrm{S}_{1}\right)$ with a planting percentage of 81,84 and 80 and were grouped as ' $b$ ', ' $a$ ' and 'b' respectively. However, there was report of declination when the speed was increased to $S_{2}$ and $S_{3}$ respectively where the percentage of single seedling planted per $\mathrm{m}^{2}$ was dropped to $62.5 \%, 76 \%$ and $70 \%$ with respect to $\mathrm{S}_{2}$ on maintaining same spacing patterns of $25 \times 25 \mathrm{~cm}, 25 \times 30 \mathrm{~cm}$ and $25 \times 40 \mathrm{~cm}$ and reported ' $\mathrm{g}$ ', 'a' and 'c' with Duncan's means grouping (Table 1). Furthermore, similar trend was also recorded when the speed was increased to $\mathrm{S}_{3}$ where a significant decrease was observed especially with the spacing pattern of $25 \times 25 \mathrm{~cm}$ with only about $56 \%$ success rate and that of $25 \times 30 \mathrm{~cm}$ having as low as $53 \%$ with the lowest reporting value of $50 \%$ at the operating speed of $\mathrm{S}_{3}$ (Figure 2 and Table 1). When pruned to $40 \mathrm{x} 40 \mathrm{~cm}$ spacing, an appreciating speed value was recorded on the same operating speed of $\mathrm{S}_{3}$. Therefore, the decrease in planting rates observed was due to the changes in speed where the speed operation of the gated opener was faster and therefore the planting mechanism was moving faster thereby causing damages on the planted seedlings. A similar trend was reportedly used by Ali et al. (2013) who recorded the highest plant height, panicles and root length with line transplanting seedlings as against the direct seeded, likewise, Dixit et al. (2007); Ali et al. (2012); Dhananchezhiyan et al. (2013); Cavallaro et al. (2014); and Islam et al. (2014) had reported on various planting geometry and further improvement by the adjusting the transplanting claws of the conventional transplanting machines although non-SRI compliance transplanting machine all targeting towards the transplanting of picking one single seedling in order to minimize the seedling density as well as reducing the competition among the growing rice plant

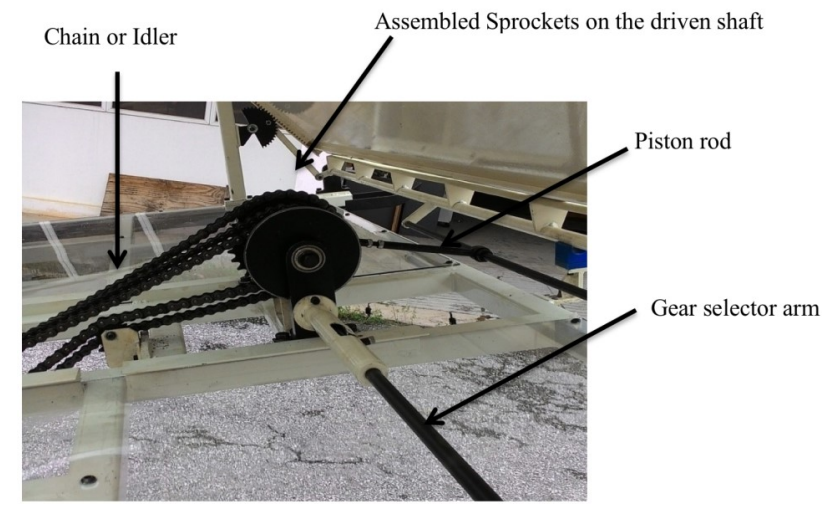

Figure 2. Assembled gear selector for spacing with in row

Table 1. Duncan's means grouping for single seedling per $\mathrm{m}^{2}$ at varying speeds

\begin{tabular}{cccc}
\hline Treatment & $\mathrm{S}_{1}$ & $\mathrm{~S}_{2}$ & $\mathrm{~S}_{3}$ \\
\hline $25 \times 25$ & $81.13^{\mathrm{b}}$ & $62.47^{\mathrm{g}}$ & $56.26^{\mathrm{g}}$ \\
$25 \times 30$ & $84.53^{\mathrm{a}}$ & $76.83^{\mathrm{a}}$ & $53.87^{\mathrm{h}}$ \\
$25 \times 40$ & $80.33^{\mathrm{b}}$ & $70.33^{\mathrm{c}}$ & $60.00^{\mathrm{f}}$ \\
$30 \times 25$ & $76.83^{\mathrm{c}}$ & $76.87^{\mathrm{a}}$ & $61.43^{\mathrm{f}}$ \\
$30 \times 30$ & $73.97^{\mathrm{d}}$ & $63.60^{\mathrm{f}}$ & $72.63^{\mathrm{d}}$ \\
$30 \times 40$ & $75.17^{\mathrm{d}}$ & $74.67^{\mathrm{b}}$ & $50.00^{\mathrm{i}}$ \\
$40 \times 25$ & $79.83^{\mathrm{b}}$ & $69.67^{\mathrm{d}}$ & $80.33^{\mathrm{b}}$ \\
$40 \times 30$ & $74.97^{\mathrm{d}}$ & $75.00^{\mathrm{b}}$ & $74.67^{\mathrm{c}}$ \\
$40 \times 40$ & $83.27^{\mathrm{a}}$ & $66.53^{\mathrm{e}}$ & $83.30^{\mathrm{a}}$ \\
\hline
\end{tabular}

Values with different alphabet superscript is significantly different $(\mathrm{p}<0.05)$. 


\subsection{Percentage of missing point per planting area}

The average seedlings pruned to missing hills at various speeds are presented in Figure 3. It was observed that seedlings planted at SRI spacing pattern of $25 \times 30$ $\mathrm{cm}$ and $30 \times 25 \mathrm{~cm}$ have indicated a significant influence on the rate of missing hills, where the recorded value of $30.8 \%$ was obtained when the speed of the operation was increased to its highest level of $0.45 \mathrm{~m} / \mathrm{s}$. Furthermore, seedlings spaced at $25 \times 25 \mathrm{~cm}$ presented the highest observation of unplanted areas with $31.2 \%$ of the overall area on which the readings were observed when the planting speed was subjected to $0.45 \mathrm{~m} / \mathrm{s}$ and this was recorded by DMRT as 'a', however, when the speed of operation was changed to $0.18 \mathrm{~m} / \mathrm{s}$ a remarkable improvement was recorded with a significant drop to $12.5 \%$ and even lower value of $7.7 \%$ when the spacing was changed to $25 \times 30 \mathrm{~cm}$. The difference was attributed as results planting speed as the rate to which the gated opener operated; thus the movement was slow at low speed thereby encouraging smooth operation of the entire planting mechanism. Similar findings were reported by Dixit et al. (2007) on transplanting performance of rice transplanting machines, Ali et al. (2013) who evaluated the planting methods of rice seedlings, Gutiérrez et al. (2009) on strawberry and Harunur et al. (2014) on variation of planting performance between direct seeded and transplanted.

\section{Percentage of missing hills vs planting speeds}

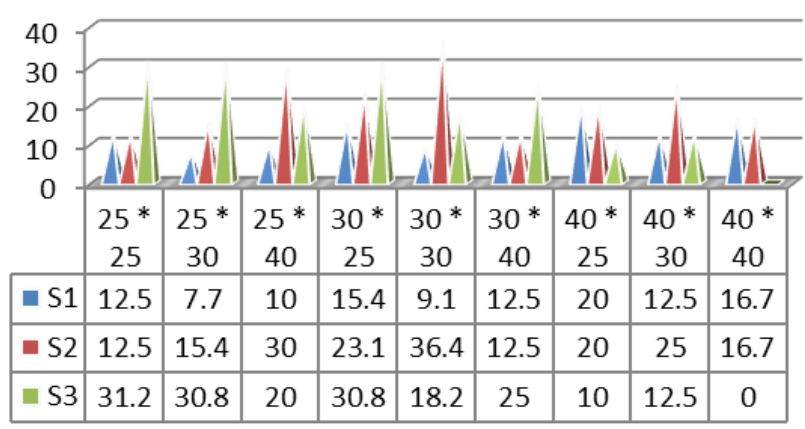

Figure 3. Percentage of missing hills per $\mathrm{m}^{2}$ at varying speeds

\subsection{Percentage of multiple planting per hill}

The percentage of multiple seedlings planted per area was also recorded at varying operational speeds $\left(\mathrm{S}_{1}\right.$, $\mathrm{S}_{2}$ and $\mathrm{S}_{3}$ ), where the data obtained revealed that seedlings planted with SRI spacing pattern of $25 \times 25 \mathrm{~cm}$ and $30 \times 40 \mathrm{~cm}$ indicated the highest significant effect with respect to multiple planting of 12.5 and $25 \%$ respectively, when the Tractor was set to high speed $\left(\mathrm{S}_{3}\right)$; thus representing a lost in single seedling planting but when compared to planting at low speed $\left(\mathrm{S}_{1}\right)$ with minimum of $6.3 \%(25 \times 25 \mathrm{~cm})$ and zero at $40 \times 40 \mathrm{~cm}$, respectively. Therefore, it can be observed that the speed of the operation had a great influence vis-à-vis to the number of multiple seedlings planting. However, data from the Duncan means grouping revealed that the speed of operation had greater impact on the performance of the SRI single seedling transplanting implement; when the speed of the operation was at $S_{1}$ lowest values of multiple planting were reported on spacing pattern of 40 $\times 25 \mathrm{~cm}(0 \%)$ and $40 \times 40 \mathrm{~cm}(0 \%)$ with both DMG of ' $\mathrm{f}$ ', respectively, but when the spacing was reduced to 25 $\times 25 \mathrm{~cm}$ it recorded a multiple planting percentage of 6.27 with a DMG of ' $\mathrm{e}$ ' with a highest Duncan grouping of value 'a' on $30 \times 30 \mathrm{~cm}$ spacing. Therefore, majority of the loss due to multiple seedlings planting was observed when the speed was increased. Thus, the lower the speed the less risk of multiple planting.

\subsection{Field capacity}

The actual field capacity was computed based on the pilot plot used at the Ladang 2, Universiti Putra Malaysia with a total area of $18 \mathrm{~m} \times 15 \mathrm{~m}=270 \mathrm{~m}^{2}$. As the test was conducted at three different speeds $\left(\mathrm{S}_{1}, \mathrm{~S}_{2}\right.$ and $\left.\mathrm{S}_{3}\right)$, therefore, the number of turning was found as Eight (8) when run along the width $18 \mathrm{~m}$ and considering the actual time taken for the Tractor to make one turn which was observed as 60 seconds and considering the number of turning, therefore, the overall time turning time to cover the area was computed as $60 \mathrm{~s} \times 8=540 \mathrm{~s}=0.13$ $\mathrm{hr}\left(\right.$ recorded as $\mathrm{T}_{\mathrm{H}}$ ). Furthermore, reloading time was also observed as $100 \mathrm{sec}=0.03 \mathrm{hr}$ (recorded as $\mathrm{T}_{\mathrm{R}}$ ), having the variation in speed; the computation for the actual field capacity and theoretical field capacity as well as the field efficiency were therefore subjected to the varying speeds. Hence, for the field operation speed of $0.18 \mathrm{~m} / \mathrm{s}$, the field efficiency was found as following the formula adopted by Murumkar et al. (2015) and Manjunatha et al. (2009) while conducting the performance evaluation of their machines:

Therefore, the overall field capacity when the SRI single seedling transplanting implement was subjected to planting of one complete hectare was computed with respect to the value obtained from the Ladang 2 field testing plot and was recorded in accordance to the variations in speed of operation. When the speed was maintained at $0.18 \mathrm{~m} / \mathrm{s}$ the field capacity indicated value of $1.29 \mathrm{ha} / \mathrm{hr}$ and this value reported an increase with increasing speed of operation with records as $1.37 \mathrm{ha} / \mathrm{hr}$ for $0.24 \mathrm{~m} / \mathrm{s}$ speed and $1.55 \mathrm{ha} / \mathrm{hr}$ for the speed of 0.45 $\mathrm{m} / \mathrm{s}$, respectively (Table 2). Similar results were reported from different research works on the variation of field capacity by Thakur et al. (2010); Sharif (2011); Pateriya and Datta (2012); Selvan et al. (2014); and Murumkar et al. (2015). 
Table 2. Field capacity at varying speeds on planting area of 0.027 ha

\begin{tabular}{cccc}
\hline & AFC (ha/hr) & TFC (ha/hr) & FE (\%) \\
\hline $\mathrm{S}_{1}$ & 0.035 & 0.044 & 79.54 \\
$\mathrm{~S}_{2}$ & 0.037 & 0.048 & 77.08 \\
$\mathrm{~S}_{3}$ & 0.042 & 0.056 & 75.00 \\
\hline
\end{tabular}

Legend: $\mathrm{S}_{1}=0.18 \mathrm{~m} / \mathrm{s} ; \mathrm{S}_{2}=0.24 \mathrm{~m} / \mathrm{s} ; \mathrm{S}_{3}=0.48 \mathrm{~m} / \mathrm{s} ; \mathrm{AFC}=$ Actual field capacity; TFC $=$ Theoretical field capacity; $\mathrm{FE}=$ Field efficiency

\section{Conclusion}

A suitable transplanting implement has been designed to serve a breakthrough in responding to the challenges of mechanized SRI transplanting to precisely transplant seedling singly with respect to Nine (9) SRI spacing options of $25 \mathrm{~cm} \times 25 \mathrm{~cm}, 25 \mathrm{~cm} \times 30 \mathrm{~cm}, 25 \mathrm{~cm}$ x $40 \mathrm{~cm}, 30 \mathrm{~cm}$ x $25 \mathrm{~cm}, 30 \mathrm{~cm}$ x $30 \mathrm{~cm}$ and $30 \mathrm{~cm} \mathrm{x} 40$ $\mathrm{cm}, 40 \times 25 \mathrm{~cm}, 40 \times 30 \mathrm{~cm}$ and $40 \times 40 \mathrm{~cm}$.

The implement was fabricated with respect to all the designed safety measures and to fully tally with the developed SRI-tray that provides soil bearing seedlings in separated cavities thereby corresponding to any soil fertility level due to the versatile ranges of spacing options.

In achieving a high percentage of seedlings' planting and spacing qualities to tally with design specifications of the implement, it is suggested that compost should be mixed in seedling media preparation.

The operating speed at $0.18 \mathrm{~m} / \mathrm{s}$ was found to have responded SRI planting and spacing geometry when compared with other speeds $(0.24 \mathrm{~m} / \mathrm{s}$ and $0.45 \mathrm{~m} / \mathrm{s})$.

The field capacity and field efficiency indicated that when the tractor maintained the speed at $0.18 \mathrm{~m} / \mathrm{s}$, the field capacity and field efficiency reported the values of $1.29 \mathrm{ha} / \mathrm{hr}$ and $79.5 \%$, respectively but, when the speed was set to $0.45 \mathrm{~m} / \mathrm{s}$, these values changed to $1.55 \mathrm{ha} / \mathrm{hr}$ and $75 \%$ respectively.

\section{Acknowledgement}

The authors express their sincere appreciation and gratitude to TetFund 2016 Intervention (Waziri Umaru Federal Poly) and Universiti Putra Malaysia for the fund released through the Research University Grant Scheme (RUGS) on project number: 05-02-12-2199RU (Vot 9376900) for the successful taking and completion of the Research.

\section{References}

Adebija, J.A. and Jackson, B.A. (2013). Performance evaluation of a manually operated cotton picker.
African Journal. of Agricultural Research, 8(29), 3883-3887. https://doi.org/10.5897/AJAR12.327

Ali., R.I., Iqbal., N., Saleem, M.U. and Akhtar, M. (2012). Effect of Different Planting Methods on Economic Yield and Grain Quality of Rice. International. Journal Agriculture and Applied. Science, 4(1), 28-34.

Ali, Q.M., Ahmad, A., Ahmed, M., Arain, M.A. and Abbas, M. (2013). Evaluation of Planting Methods for Growth and Yield of Paddy (Oryza sativa L.) Under Agro-Ecological Conditions of District Shikarpur. American Eurasian Journal of Agriculture and Evironmental Science, 13(11), 1503 -1508 . https://doi.org/10.5829/ idosi.aejaes.2013.13.11.11259

Behera, B.K., Varshney, B.P. and Goel, A.K. (2009). Effect of Puddled Soil Characteristics and Performance of Self-propelled Transplanter in Rice Crop. Agricultural Engineering International: CIGR Journal, 11, 1-18.

Brown, C.C. and Funk, M.E. (2008). Food Security under Climate Change. Science, 319, 580-581. https://doi.org/10.1126/science.1154102

Bruinsma, J. (2009). The resource outlook to 2050: By how much do land, water and crop yields need to increase by 2050? Expert Meeting on How to Feed the World in 2050, 24-26 June 2009. Rome: FAO

Cavallaro, D., Chin, M., O'Connor, L. and Ruiz, D. (2014). A New Rice Sowing Technology : Informing Small-Scale Farmers about Improved Methods of Planting A New Rice Sowing Technology: Informing Small-Scale Farmers about Improved Methods of Planting. Thailand: Chulalongkorn University.

Chiu, Y.-C. and Fon, D.-S. (2000). Development of an Automatic Rolling System for Rice Seedlings. Journal of Agricultural Engineering Research, 76 (2), 149-156. https://doi.org/10.1006/jaer.2000.0539

Dhananchezhiyan, P., Durairaj, C.D. and Parveen, S. (2013). Development of nursery raising technique for "system of rice intensification" machine transplanting. African Journal of Agricultural Research, 8(29), 3873-3882. https:// doi.org/10.5897/AJAR2013.7465

Dixit, A., Khurana, R., Singh, J. and Singh, G. (2007). Comparative Performance of Different Paddy Transplanters Developed in India - A Review. Agricultural. Review, 28(4), 262-269.

Ersson, B.T., Bergsten, U. and Lindroos, O. (2011). The Cost-Efficiency of Seedling Packaging Specifically Designed for Tree Planting Machines. Silva Fennica, 45(3), 379-394. https://doi.org/10.14214/sf.108 
FAO., WFP. and IFAD (2012). The State of Food Insecurity in the World 2012: Economic Growth is Necessary but not Sufficient to Accelerate Reduction of Hunger and Malnutrition. Rome: FAO.

FAOSTAT. (2012). FAOSTAT 2012: Production - Crop, 2012 data. Rome: Food and Agricultural Organisation of the United Nation.

Farooq, M., Siddique, K.H.M., Rehman, H., Aziz, T., Lee, D.-J. and Wahid, A. (2011). Rice direct seeding: Experiences, challenges and opportunities. Soil and Tillage Research, 111(2), 87-98. https:// doi.org/10.1016/j.still.2010.10.008

Godfray, H.C.J., Beddington, J.R., Crute, I.R., Haddad, L., Lawrence, D., Muir, J.F., Pretty, J., Robinson, S., Thomas, S.M. and Toulmin, C. (2010). Food security: the challenge of feeding 9 billion people. Science, 327(5967), 812-818. https:// doi.org/10.1126/science. 1185383

Gutiérrez, C., Serwatowski, R., Gracia, C., Cabrera, J.M. and Saldaña, N. (2009). Design, building and testing of a transplanting mechanism for strawberry plants of bare root on mulched soil. Spanish Journal of Agricultural Research, 7(4), 791-799. https:// doi.org/10.5424/sjar/2009074-1093

Harunur Rashid, M., Nargis, P., Rahman Dewan, M. and Hazrat Ali, M. (2014). Productivity Of Dry Seeded And Transplanted Rice (Oryza sativa) in Aman Season. Bangladesh Journal of Agricultural Research, 39(1), 185-187. https://doi.org/10.3329/ bjar.v39i1.20171

Hussain, S., Ramzan, M., Rana, M.A., Mann, R.A., Akhter, M. and Kaku, K.S. (2013). Effect of Various Planting Techniques on Yield and Yield Components of Rice Introduction. The Journal of Animal and Plant Sciences, 23(2), 672-674.

Islam, M.S., Sarkar, M.A.R., Alam, M.J., Kashem, M.A., Rafii, M.Y. and Latif, M.A. (2014). Effect of Number of Seedling per Hill on the Growth and Yield of Aromatic Fine Rice Varieties in Rain fed Condition. Life Science Journal, 11(8), 109-115.

Joshi, E., Kumar, D., Lal, B., Nepalia, V., Gautam, P. and Vyas, A.K. (2013). Management of direct seeded rice for enhanced resource - use efficiency. Plant Knowledge Journal, 2(3), 119-134.

Lutfar Rahman, M. (2013). Effect of Hill Spacing and Number of Seedlings. Bangladesh: Bangladesh Agricultural University, Thesis

Madusanka, H.K.S. (2011). Design and Development of Paddy Seedling Transplanting. Sri Lanka: University of Peradeniya, BSc. Thesis.

Manjunatha, M.V, Reddy, B.G.M., Shashidhar, S.D. and Joshi, V.R. (2009). Studies on the performance of self-propelled rice transplanter and its effect on crop yield. Karnataka Journal of Agricultural Science, 22 (2), 385-387.

Murumkar, R.P., Dongarwar, U.R., Phad, D.S., Borkar, B.Y. and Pisalkar, P.S. (2015). Performance Testing of Four Row Self Propelled. International Journal of Science, Environment and Technology, 3(6), 20152019.

Ojha, P. and Kwatra, S. (2014). Analysis of different paddy transplanting methods in northern India : Ergo - economical study. Journal of Applied and Natural Science, 6(2), 654-658. https://doi.org/10.31018/ jans.v6i 2.512

Pateriya, R.N. and Datta, R.K. (2012). Design Modifications of Mat Type Rice Transplanter. International Journal of Advanced Technology and Engineering Research, 2(6), 2-6.

Selvan, M.M., Annamalai, S.J.K., Thavaprakash, N. and Ananathakrishnan, D. (2014). Design and development of three-row improved pull-type rice transplanter for small farmers. Indian Journal of Agricultural Science, 84(11), 1422-1427.

Sharif, A. (2011). Technical adaptations for mechanized SRI production to achieve water saving and increased profitability in Punjab, Pakistan. Paddy and Water Environment, 9(1), 111-119. https:// doi.org/10.1007/s10333-010-0223-5

Thakur, A.K., Rath, S., Roychowdhury, S. and Uphoff, N. (2010). Comparative Performance of Rice with System of Rice Intensification (SRI) and Conventional Management using Different Plant Spacings. Journal of Agronomy and Crop Science, 196(2), 146-159. https://doi.org/10.1111/j.1439037X.2009.00406.X

Zubairu U.B., Wayayok, A., Amin, M.S.M. and Bande, Y.M. (2015). Sri-Tray: Breakthrough in Nursery Management for the System of Rice. Jurnal Teknologi (Sciences and Engineering), 78(1-2), 6571. 